\title{
Characterization of a Salmonella enterica serotype Pullorum isolated from a lizard co-habitating with poultry
}

\author{
A. O. Ogunleye ${ }^{1 *}$, A. T. P. Ajuwape ${ }^{1}$, O. O. Alaka ${ }^{2}$ and A. I. Adetosoye ${ }^{1}$ \\ ${ }^{1}$ Department of Veterinary Microbiology and Parasitology, University of Ibadan, Ibadan, Oyo State, Nigeria. \\ ${ }^{2}$ Department of Veterinary Pathology, University of Ibadan, Ibadan, Oyo State, Nigeria.
}

Accepted 15 March, 2013

\begin{abstract}
Salmonella is one of the most important pathogens associated with gastrointestinal infections in warmblooded animals. Lizards have been incriminated in the transmission of Salmonellae and other enteric pathogens through contaminated soil, food, or water. In the current study, we characterized a Salmonella isolate, recovered from the small intestine of an Agama agama lizard captured in a poultry pen from Teaching and Research Farm, University of Ibadan, Nigeria. The characterization was based on serotyping, polymerase chain reaction (PCR)-based confirmation of the serotype, multiplex PCR identification of selected beta-lactam genes associated with $3^{\text {rd }}$ generation cephalosporin resistance and pathogenicity experiment of the isolate in pullet. Our work identified the isolate as Salmonella enterica serotype Pullorum that had apparently lost its fimbriae 1 antigen due to sub-culturing prior to serotyping. The isolate also carried transferable $3^{\text {rd }}$ generation cephalosporin resistant genes and produced $28 \%$ mortalities in 16 weeks old birds during 21days pathogenicity experimentation. This work reveals the potential roles of Agama agama lizards regarding the epidemiology of Salmonella infections and possible involvement in the spread of antibiotic drug resistant pathogens in poultry.
\end{abstract}

Key words: Salmonella, Agama agama, $3^{\text {rd }}$ generation - cephalosporins, Nigeria.

\section{INTRODUCTION}

Salmonella is one of the most important pathogens associated with gastrointestinal infections in warmblooded animals (Bopp et al., 2003). These important food-borne pathogens are demonstrating increasing antimicrobial resistance rates (Ahmed et al., 2009).

Recently, CDC (2012) reported multistate outbreaks of human Salmonella infections linked to exposure to turtles or their environments. Lizards are widely distributed in nature, and many species (e.g., Pogona vitticeps, Agama agama, Gecko gecko and Hemidactylus)thrive in the vicinity of humans and domesticated animals (Kourany et al., 1970; Oboegbulem and Iseghohimhen, 1985; Cooke et al., 2009). These lizards have been identified as potential carriers and/or reservoirs of pathogenic organisms for humans and animals (Kourany et al., 1970; Kourany and Telford, 1981). They have been incriminated in the transmission of Salmonellae and other enteric pathogens through their direct or indirect contamination of soil, food, or water sources (Kourany and Porter, 1969; Kourany et al., 1970., Kourany and Telford, 1981).

In Nigeria, Agama agama lizards are commonly seen in and out of animal houses, particularly poultry pens. They sometimes have unfettered access to animal feeds and water.

Various Salmonella serotypes (such as Weltevreden, 
Typhimurium, Enteritidis, Hvittingfos, Saint-paul, and Agama) have been reported in lizards from Nigeria (Oboegbulem and Iseghohimhen, 1985). Recently, two Salmonella strains were recovered from the intestines of $2 \%$ of Agama agama lizards captured in some poultry pens in a Teaching and Research farm in Nigeria (Ogunleye et al., 2010). The current work characterized one of the two isolates by serotyping, genotypic analyses of beta-lactamase genes and pathogenicity of the isolate in pullets.

\section{MATERIALS AND METHODS}

\section{The Salmonella isolate}

The Salmonella enterica isolate used for this study was isolated from the intestine of one of 100 Agama agama lizards captured from poultry pens in the University of Ibadan Teaching and Research Farm, Nigeria (Ogunleye et al., 2010). The isolate was studied for antimicrobial susceptibility to, ciprofloxacin > 98\% HPLC (17850-5G), kanamycin sulfate $785 \mu \mathrm{g} / \mathrm{mg}$ (N6386- 5G), chloramphenicol (C1919-5G), streptomycin sulfate salt 775 units/mg (S6501-5G), neomycin trisulfate salt $689 \mu \mathrm{g} / \mathrm{mg}$ (N6386$5 \mathrm{G}$ ), nalidixic acid sodium salt (N4382-5G), ampicillin sodium salt 91.5 to $100.5 \%$ (A9518-5G) and tetracycline hydrochloride (T76605G) (Sigma Aldrich, Inc., 3050 Spruce Street, St Loius, Mo63103 USA). The isolate was resistant to tetracycline, ampicillin, chloramphenicol, kanamycin, nalidixic acid neomycin and ciprofloxacin but sensitive to streptomycin at MIC of $2 \mu \mathrm{g} / \mathrm{mL}$ and transferred the $\mathrm{R}$ factors for tetracycline, ampicillin, chloramphenicol, kanamycin, nalidixic acid and neomycin En bloc to sensitive Escherichia coli $356 \mathrm{~K} 12$ that is resistant to $200 \mu \mathrm{g} / \mathrm{mL}$ of streptomycin courtesy Dr J.R. Walton, University of Liverpool in a conjugation experiment (Ogunleye et al., 2010).

\section{Serotyping of the isolates}

The isolate was sub-cultured into trypticase soy agar (TSA) and submitted to National Veterinary Service Laboratories in Ames, lowa, USA for serotyping. Serotyping was performed according to the Kauffman-White Scheme.

\section{PCR identification of the isolate}

Chromosomal DNA was produced from the isolate by heating overnight $L B$ broth culture at $99^{\circ} \mathrm{C}$ for 15 min. A $50 \mu \mathrm{l} \mathrm{PCR} \mathrm{reaction}$ was performed containing of 20 pmoles of the respective forward and reverse oligonucleotides that differentiate $S$. enterica serotype Pullorum and $S$. enterica serotype Gallinarum (Pullorum and Gallinarum, $F=5$ 'CTGGGCATTGACGCAAA3' and $\mathrm{R}=5^{\prime}$ CGGTGTACTGCCCGCTAT3'; Gallinarum-only, $\mathrm{F}=5$ 5'GATCTGCTGCCAGCTCAA3' $^{\prime}$ and $\mathrm{R}=5^{\prime}$ 'GCGCCCTTTTCAAAAACATA3'), 10X Buffer, $3 \mu \mathrm{L}$ of $1.5 \mathrm{mM}$ $\mathrm{MgCl}_{2}, 3 \mu \mathrm{L}$ each of $250 \mu \mathrm{M}$ of each deoxynucleoside triphosphate, $0.2 \mu \mathrm{L}$ containing 1.25 units of Taq polymerase, and $2 \mu \mathrm{L}$ of boiled DNA template. Crude DNA samples of $S$. enterica serotype Pullorum and $S$. enterica serotype Gallinarum were used as positive controls for the respective pairs of the oligosequences.

BIO-RAD MJ Mini personal Thermal cycler was used for the DNA amplification using the following PCR protocol: initial denaturation at $95^{\circ} \mathrm{C}$ for $2 \mathrm{~min}$, followed by 40 cycles of $95^{\circ} \mathrm{C}$ for $1 \mathrm{~min}, 53^{\circ} \mathrm{C}$ for $30 \mathrm{~s}$, and $70^{\circ} \mathrm{C}$ for $45 \mathrm{~s}$. Amplified DNA products were resolved using $1 \%(\mathrm{w} / \mathrm{v})$ agarose gel electrophoresis.
Determination of resistance to cefotaxime, ceftazidime, cefovecin, ceftriaxone, cefpirome and ceftiofur

The Salmonella serotype was grown aerobically in breakpoint concentrations $(32 \mu \mathrm{g} / \mathrm{ml})$ of cefotaxime, ceftazidime, cefovecin, ceftriaxone, cefpirome and ceftiofur (all obtained from SIGMAALDRICH) according to standard method (CLSI, 2009). Resistance was ascribed if flocculent growth was observed after $16 \mathrm{~h}$ of aerobic growth at $37^{\circ} \mathrm{C}$.

\section{Plasmid DNA isolation}

Plasmid DNA was isolated from the Salmonella isolate using QIAGEN $^{\circledR}$ Large-Construct Kit (QIAGEN Companies) as per the manufacturer's protocol.

\section{Amplification of the genes encoding $3^{\text {rd }}$ generation cephalosporin resistance}

Fourteen (14) sets of primers (forward and reverse oligosequences (Table 1), targeted the following gene classes: TEM, SHV, CTX, PER, DHAM, VEB, GES, OXA2, ACCM, CITM, FOXM, ECBM, MOX and OXA10 were used to amplify the respective genes from plasmid DNA of the isolate. PCR was performed in a $50 \mu \mathrm{l}$ reactions containing $5 \mu \mathrm{l}$ of $10 \mathrm{X}$ Buffer, $3 \mu \mathrm{l}$ of $1.5 \mathrm{mM} \mathrm{MgCl}_{2}, 3 \mu \mathrm{l}$ each of $250 \mu \mathrm{M}$ of each deoxynucleoside triphosphate, $2 \mu \mathrm{l}$ each of $10 \mathrm{pmol}$ of the respective forward and reverse primers, $0.5 \mu \mathrm{l}$ of Taq polymerase and $2 \mu \mathrm{l}$ of plasmid DNA template and $32.5 \mu \mathrm{l}$ of water. BIO-RAD MJ mini personal thermal cycler was used for the DNA amplification using the following PCR protocol: initial denaturation at $95^{\circ} \mathrm{C}$ for $2 \mathrm{~min}$, followed by 40 cycles of $95^{\circ} \mathrm{C}$ for $1 \mathrm{~min}, 53^{\circ} \mathrm{C}$ for $30 \mathrm{~s}$ and $70^{\circ} \mathrm{C}$ for $45 \mathrm{~s}$. Amplified DNA products were resolved using $1 \%(\mathrm{w} / \mathrm{v})$ agarose gel electrophoresis.

\section{Pathogenicity experiment with poultry}

\section{Experimental birds}

The 50 Golden Comet $^{\circledR}$ pullets used for the pathogenicity experiment were selected from a group of 250 pullets donated by Amo Byng Nigeria Limited ${ }^{\circledR}$, Awe, Oyo State Nigeria. Approved Institutional Animal Care guidelines were followed for work with the birds. The chicks were raised under strict hygienic conditions in experimental cage facilities at the Faculty of Veterinary Medicine, University of Ibadan, Nigeria. The chicks were fed ad libitum with antibiotic-free commercial chick mash donated by the feed meal unit of the Hope Farms ${ }^{\circledR}$ Ltd, Ibadan, Oyo State, Nigeria up to the $9^{\text {th }}$ week of age. From the $9^{\text {th }}$ week to the end of the experiment, they were fed with antibiotic-free commercial growers mash donated by Amo Byng Nigeria Limited ${ }^{\circledR}$.

The birds were routinely vaccinated with the National Veterinary Research Institute $\left(\mathrm{NVRI}^{\circledR}\right)$ Vom, Plateau State, Nigeria vaccines against: Newcastle disease on the $1^{\text {st }}$ and $16^{\text {th }}$ days; and $6^{\text {th }}$ and $10^{\text {th }}$ week (using intra ocular and Lasota vaccines, Lasota and Komorov vaccine, respectively). The Infectious Bursal Disease (Gumboro, Live attenuated) vaccine were administered on the $8^{\text {th }}$ and $18^{\text {th }}$ days and in the $4^{\text {th }}$ week of age, respectively. The birds were dewormed in the $9^{\text {th }}$ and $11^{\text {th }}$ weeks of age respectively using piperazine (piperazine wormer Pfizer ${ }^{\circledR}$ products Plc, Ikeja, Nigeria) at dosage of $0.7 \mathrm{~g} / \mathrm{l}$ drinking water.

At the $16^{\text {th }}$ week of age, cloaca swabs of the 50 birds out of 250 birds were examined bacteriologically for Salmonella by Standard methods (Ewing, 1986; Barrow and Feltham, 1993). They were subsequently used for the pathogenicity experiment. 
Table 1. The fourteen beta-lactamases genes, the primers oligosequences and related beta-lactamases.

\begin{tabular}{|c|c|c|c|c|}
\hline $\mathbf{S} / \mathbf{N}$ & $\begin{array}{l}\text { Resistance } \\
\text { Gene }\end{array}$ & $\begin{array}{c}\text { Base pairs } \\
\text { number }\end{array}$ & Oligosequence & Related enzyme(s) \\
\hline 1 & TEM & 931 & $\begin{array}{l}\text { F=5'TCCGGTCATGAGACAATAACC3' } \\
\text { R=5'TTGGTCTGACAGTTACCAATGG3' }\end{array}$ & TEM1-TEM190. \\
\hline 2 & SHV & 868 & $\begin{array}{l}\text { F=5'TGGTTATGCGTTATATTCGCC3' } \\
\text { R=5'GGTTAGCGTTGCCAGTGCT3' }\end{array}$ & SHV1-SHV63 \\
\hline 3 & CTX & 909 & $\begin{array}{l}\mathrm{F}=5^{\prime} \text { 'TCTTCCAGAATAAGGAATCCC }{ }^{\prime} \\
\mathrm{R}=5^{\prime} \text { 'CCGTTTCCGCTATTACAAA3' }\end{array}$ & СTX-M-1-CTX-M-82. \\
\hline 4 & PER & 927 & $\begin{array}{l}\mathrm{F}=5^{\prime} \text { ATGAATGTCATCACAAAATG3' } \\
\mathrm{R}=5^{\prime} \text { TCAATCCGGACTCACT3' }\end{array}$ & PER1 and PER2 \\
\hline 5 & DHAM & 405 & $\begin{array}{l}\mathrm{F}=5^{\prime} \text { AACTTTCACAGGTGTGCTGGGT3' } \\
\mathrm{F}=5^{\prime} \text { 'CCGTACGCATACTGGCTTTGC3' }\end{array}$ & DHA1 and DHA2. \\
\hline 6 & VEB & 914 & $\begin{array}{l}\mathrm{F}=5^{\prime} \text { GATAGGAGTACAGACATATG3' } \\
\mathrm{R}=5^{\prime}{ }^{\prime T T T A T T C A A A T A G T A A T T C C A C G 3 ' ~}\end{array}$ & VEB1 and VEB2. \\
\hline 7 & GES & 864 & $\begin{array}{l}\mathrm{F}=5^{\prime} \text { ATGCGCTTCATTCACGCAC3' } \\
\mathrm{R}=5^{\prime} \text { CTATTTGTCCGTGCTCAGG3' }\end{array}$ & GES1 and GES 2. \\
\hline 8 & OXA-2 & 478 & $\begin{array}{l}\mathrm{F}=5^{\prime} \text { AAGAAACGCTACTCGCCTGC3' } \\
\mathrm{R}=5^{\prime} \text { 'CCACTCAACCCATCCTACCC3' }\end{array}$ & OXA1, OXA2 andOXA15. \\
\hline 9 & ACCM & 346 & $\begin{array}{l}\mathrm{F}=5^{\prime} \text { AACAGCCTCAGCAGCCGGTTA3' } \\
\mathrm{R}=5^{\prime} \text { TTCGCCGCAATCATCCCTAGC3' }\end{array}$ & ACC only. \\
\hline 10 & CITM & 462 & $\begin{array}{l}\mathrm{F}=5^{\prime} \text { TGGCCAGAACTGACAGGCAAA3' } \\
\mathrm{R}=5^{\prime} \text { TTTCTCCTGAACGTGGCTGGC3' }\end{array}$ & LAT1-LAT4, CMY2-CMY7, BIL1. \\
\hline 11 & FOXM & 190 & $\begin{array}{l}\mathrm{F}=5^{\prime} \text { AACATGGGGTATCAGGGAGATG3' } \\
\mathrm{R}=5^{\prime} \text { CAAAGCGCGCGTAACCGGATTGG3' }\end{array}$ & FOX1-FOX5b. \\
\hline 12 & ECBM & 302 & $\begin{array}{l}\mathrm{F}=5^{\prime} \text { TCGGTAAAGCCGATGTTGCGG3' } \\
\mathrm{R}=5^{\prime} \text { CTTCCACTGCGGCTGCCAGTT3' }\end{array}$ & MIR-1T and ACT-1. \\
\hline 13 & MOX M & 520 & $\begin{array}{l}\mathrm{F}=5^{\prime} \text { 'GCTGCTCAAGGAGCACAGGAT3' } \\
\text { R=5'CACATTGACATAGGTGTGGTGC3' }\end{array}$ & MOX1, MOX2, CMY-1, CMY8-CMY11. \\
\hline 14 & OXA 10 & 720 & $\begin{array}{l}\mathrm{F}=5^{\prime} \text { 'GTCTTTCGAGTACGGCATTA3' } \\
\mathrm{R}=5^{\prime} \text { ATTTTCTTAGCGCAACTTAC3' }\end{array}$ & $\begin{array}{l}\text { OXA10,OXA17, OXA56, OXA79, } \\
\text { OXA16, OXA14. }\end{array}$ \\
\hline
\end{tabular}

\section{Pathogenicity test}

At $16^{\text {th }}$ week 25 of the 50 Golden Comet $^{\oplus}$ pullets selected that tested negative for Salmonella were housed in one cage designated "experimental birds", while the remaining twenty five (control) were housed in another cage. A viable count was effected $24 \mathrm{~h}$ after incubation at $37^{\circ} \mathrm{C}$ of broth culture of $S$. enterica isolated from the intestine of lizard using the plate count method by Miles et al. (1938) to determine the concentration of the infective dose. Each experimental bird was fed orally with $0.5 \mathrm{ml}$ of the $8 \mathrm{~h}$ broth containing $1 \times 10^{8} \mathrm{CFU} / \mathrm{ml}$ of the Salmonella isolate, while the control birds were fed orally with $0.5 \mathrm{ml}$ of sterile trypticase soy broth (TSB) each. The two groups were subsequently given growers' mash rations and water without antibiotics ad- libitum. The birds were observed daily for clinical signs and dead birds were taken for post-mortem examination within 21 days of 


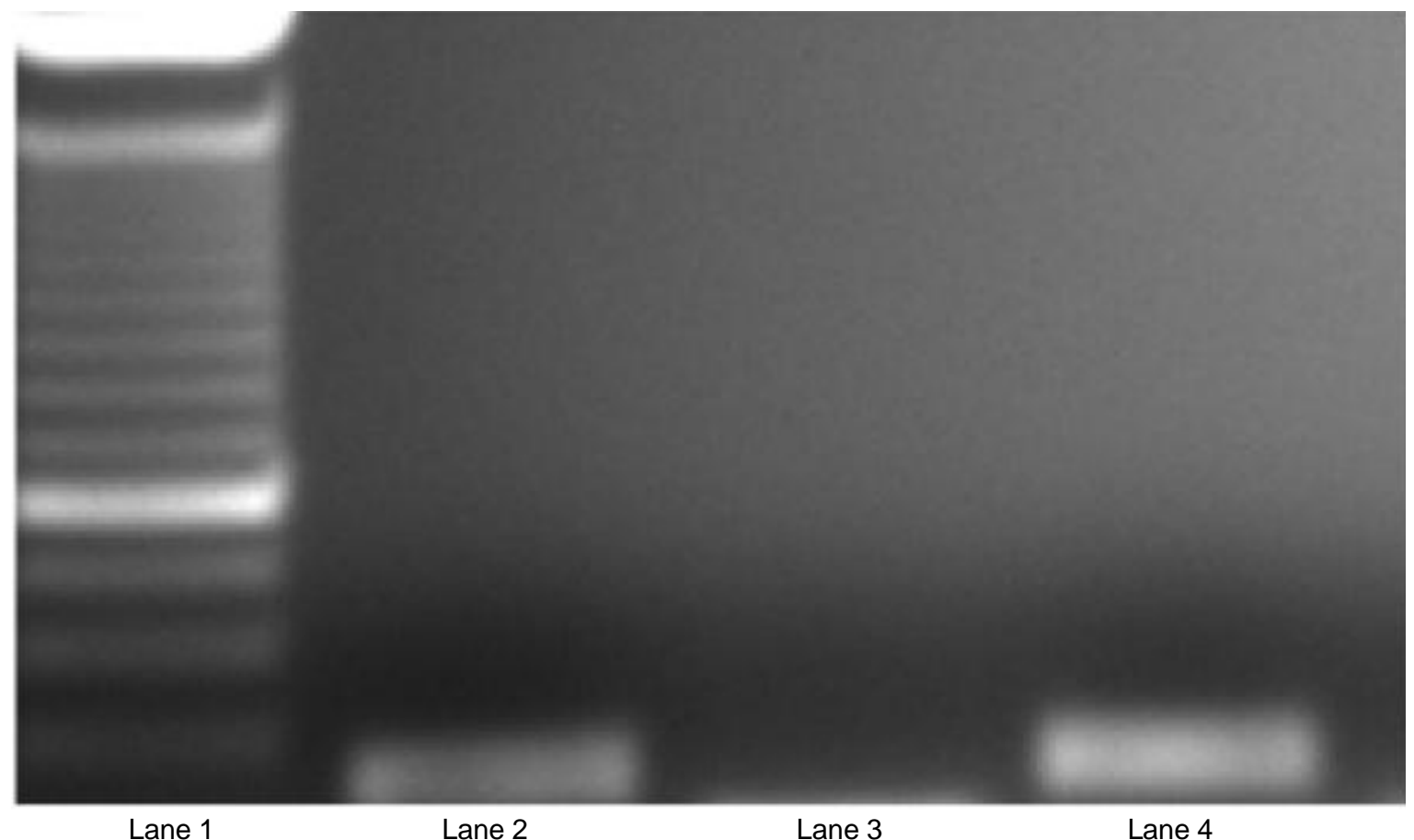

Figure 1. Gel picture of the amplicons obtained from the lizard isolate. An amplicon was observed following PCRbased amplification with Pullorum/Gallinarum-specific primers (Lane 2) but not Gallinarum-specific primers (Lane 3). The positive control using a known Salmonella enterica serotype Pullorum isolate is presented in Lane 4 . The molecular weight standard is present in Lane 1.

experimentation.

\section{Bacteriology and histopathology}

Specimens were taken aseptically from the liver, small intestines, spleen, heart and heart blood, and bone marrow of dead birds from the infected group for bacteriological and histopathological examinations. The bacteriological specimens were stored in the deep freezer at $-20^{\circ} \mathrm{C}$, in the Department of Veterinary Microbiology and Parasitology at the University of Ibadan, until they were examined by standard methods (Ewing, 1986; Barrow and Feltham, 1993; Abouzeed et al., 2000). Histopathological specimen were fixed in $10 \%$ formalin and processed routinely for histopathological examination (Raphael, 1976).

\section{RESULTS}

Our results identified the isolate as $S$. enterica serotype Pullorum carrying some genes encoding beta-lactamases resistance capable of causing transferable resistance in animals and human.

Serotype analysis showed the isolate as 9,12:Nonmotile which was presumably Salmonella enterica serotype Pullorum $(1,9,12)$ that lost its fimbrial antigen 1 due to long-term sub-culturing prior to serotype analysis. As shown in Figure 1, an amplicon was obtained using the Pullorum/Gallinarum-specific primers while no amplicon was observed following amplification with the Gallinarum-specific oligonucleotides. The
Salmonella enterica serotype Pullorum isolated from the intestine of the lizard had the following minimum inhibitory concentrations for the respective antibiotics; Ciprofloxacin $>30 \mu \mathrm{g} / \mathrm{ml}$, chloramphenicol $50 \mu \mathrm{g} / \mathrm{ml}$, Kanamycin $>30 \mu \mathrm{g} / \mathrm{ml}$, nalidixic acid $100 \mu \mathrm{g} / \mathrm{ml}$, neomycin $\geq 35 \mu \mathrm{g} / \mathrm{ml}$, ampicillin $>35 \mu \mathrm{g} / \mathrm{ml}$, streptomycin $2 \mu \mathrm{g} / \mathrm{ml}$, tetracycline $>35 \mu \mathrm{g} / \mathrm{ml}$.

In the conjugation experiment, the isolate transterred the R-factors for tetracycline, ampicillin, kanamycin, neomycin, chloramphenicol and nalidixic acid to $E$ coli $365 \mathrm{~K}_{12}$ resistant to $200 \mu \mathrm{g} / \mathrm{ml}$ streptomycin used as sensitive recipient. The isolate was however only resistant to cefpirome at $32 \mu \mathrm{g} / \mathrm{ml}$ breakpoint out of the six $3^{\text {rd }}$ generation cephalosporin; namely cefotaxime, ceftazidime, cefovecin, ceftriaxone, cefpirome and ceftiofur tested. The cefpirome resistant $S$. enterica serotype Pullorum isolated from lizard harboured: TEM, DHAM, ACCM, FOXM from the entire 14 genes screened for.

The cloaca swab samples of the 50 pullets used for the pathogenicity experiment did not yield growth of Salmonella species. The birds in the experimental group showed no apparent clinical sign until nine days postinoculation when the first mortality was recorded. From day 9 post-inoculation, the birds became progressively inactive with mortality increasing progressively and reached $28 \%$ by 15 days post-inoculation. The fatality remained at $28 \%$ by 21 days post inoculation when the 


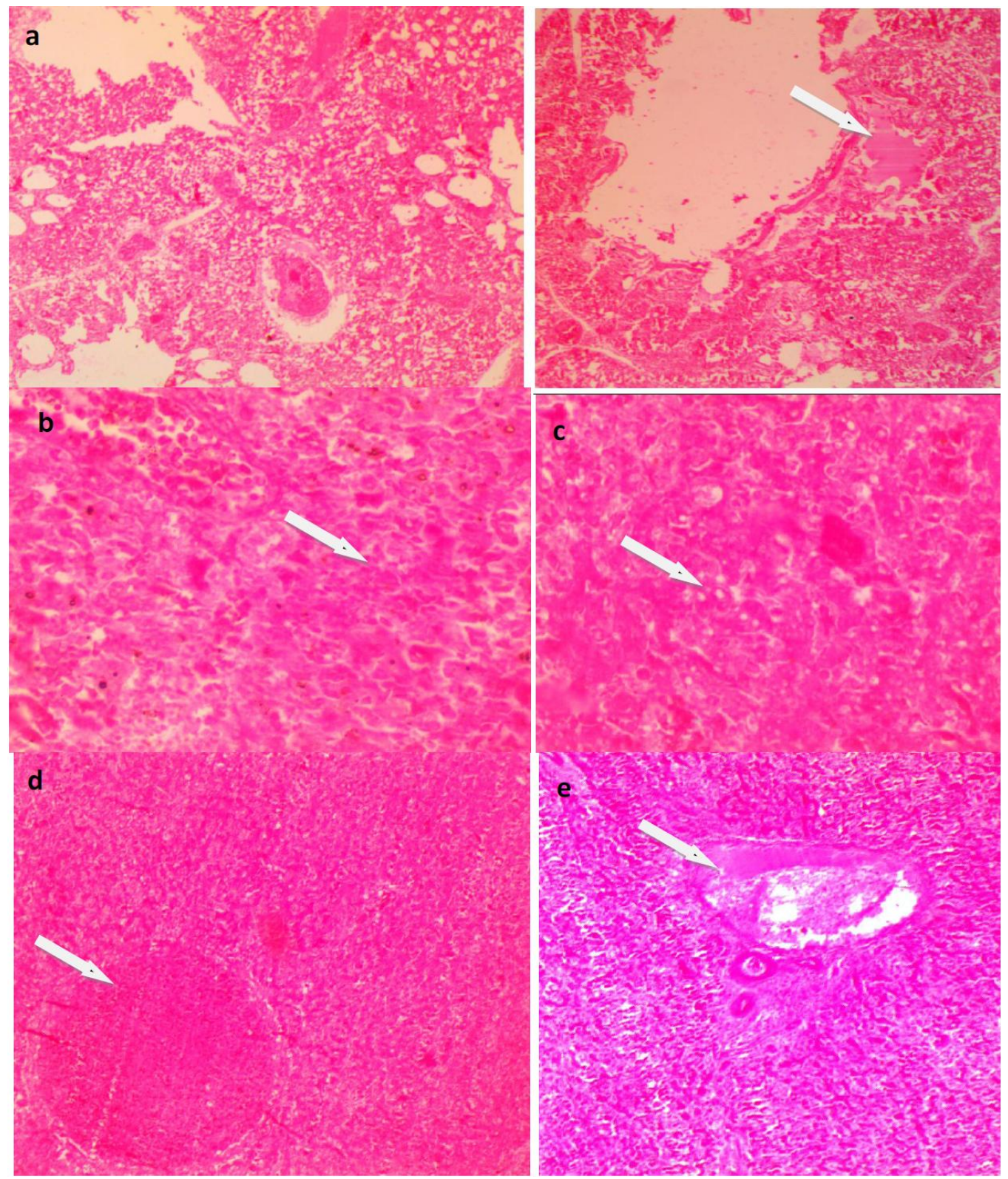

Figure 2. Photomicrographs of some organs illustrating some of the observed pathological changes. a. Photomicrographs of lung section showing diffuse hyperaemia and edema (arrow) H\&E X160. b. Section from liver showing extensive hepatic necrosis (arrow) H\&E X 160. c. Section from liver showing vacuolar degeneration of hepatocytes (arrow). H\&E X 160. d. Section from liver showing congestion of hepatic blood vessels (arrow) H\&E X 160. e. Section from liver showing thrombosis within hepatic blood vessels (arrow) H\&E X 160.

experiment was terminated.

Some of the birds subjected to post-mortem examination showed significant lesions both at the gross and histopathological levels. The livers, kidneys, lungs and intestines were mostly affected. The livers showed extensive hepatic necrosis (Figure 2b), vacuolar degeneration of hepatocyte (Figure 2c), congestion of hepatic blood vessel (Figure 2d), and thrombosis within hepatic blood vessel (Figure 2e). The intestines showed diffuse hyperaemia of the mucosa with segmental haemorrhages in the duodenum and ileum. The lamina propriae were diffusely thickened with severe mononuclear cellular infiltrations. The inflammatory cells were predominantly lymphocytes with lesser numbers of macrophages and plasma cells.

Varying degrees of edema and hyperemia were the lesions consistently seen in the lungs (Figure $2 a$ ), while the kidneys showed diffuse hyperaemia of blood vessels only. No significant lesions were observed in the organs from birds in the negative control group. 


\section{DISCUSSION}

Salmonella Pullorum and Gallinarum are similar in many ways. For instance, they are both characterized as Salmonella enterica subspecies enterica (group D) (somatic antigen 1,9 and 12), both lacks flagella and grows slowly in cultured media compared with other Salmonella (Berchieri Jr., 2000). Due to the similarities in their antigenic and biochemical characteristics, genetical analysis of both is often used for their differentiation. For example in a work by Ribeiro et al. (2009), They analysed speC gene (the gene associated with the metabolism of the amino acid ornithine; usually decarboxylated by Salmonella Pullorum and not by Salmonella Gallinarum). From the 21 Salmonella Pullorum and 15 Salmonella Gallinarum analysed by PCR assay, both Salmonella serovars produced fragments that are identical at 2000bp (Ribeiro et al., 2009). The differences in the serovars were only spotted after treatment with restriction enzyme Eco RI (Ribeiro et al., 2009).

This study describes the characterization of Salmonella serotype isolated from intestine of an Agama agama lizard captured in a poultry pen in the University of Ibadan Teaching and Research farm, Nigeria. The characterization was based on serotyping, genotyping of serotype-specific genes, and genotyping of certain $3^{\text {rd }}$ generation cephalosporin resistance genes. The cefpirome resistance in this $S$. enterica serotype Pullorum isolate is most likely due to the presence of TEM, as earlier observed in some cefpirome resistant Salmonella serotypes from Nigeria in an earlier work by Ogunleye and Carlson (2011). The other genes like DHAM, ACCM and FOXM are not typically associated with cefpirome resistance (Ogunleye and Carlson, 2011). The PCR analysis of Pullorum/Gallinarum sequences confirms our hypothesis that the 9,12:Nonmotile result from the serotype was a $S$. Pullorum that had lost its fimbrial 1 antigen due to long-term sub-culturing prior to serotype analysis (Figure 1).

Reptiles are often asymptomatic carriers of Salmonellae (Kaufmann et al., 1967; Jackson and Jackson, 1971; Otis and Behler, 1973) and cases of clinical Salmonellosis associated with them are rare (Will, 1975; Frye, 1981; Marcus, 1981). Lizards are particularly known to be frequent carriers of Salmonella in their intestinal tract (Zwart, 1960; Zwart and Poelma, 1970; Cambre et al., 1980; Greenberg and Sechter, 1992; Monzon - Moreno et al., 1995; Geue and Löschner, 2002); although, it has been reported that most of the Salmonella isolates from lizards belong to serovars that are not usually encountered in mammals and birds (Bäumler et al., 1998). The current $S$. Pullorum recovered from the intestine of a lizard captured in a poultry pen, which also produced $28 \%$ mortality in pullet in a pathogenicity experiment, is indicative of the possible role of lizards in the transmission Salmonella infections in poultry. The need to consider the role of lizard in the transmission of Salmonella Pullorum is imperative, against the backdrop of easy access of lizards to feed and water sources in poultry houses in Nigeria with resultant risk of contamination. In addition, the presence of some genes encoding beta-lactamases capable of causing transferable antibiotic resistance in this isolate underscores a possible health risk in terms of transfer of drug resistance pathogen from the lizard to poultry and possibly ultimately to human thus constituting a possible public health risk. Recently, CDC (2012) incriminated pet turtles in human Salmonella infections that have sickened 66 people in 16 States of United States of America. The pathogenicity of the isolate for pullets brings to light the possible involvement of Agama lizard in the epidemiology of Salmonella infections in poultry.

\section{ACKNOWLEDGEMENTS}

We appreciate the Managing Directors and the entire staff of Amo Bygn ${ }^{\circledR}$ Nigeria Ltd, Awe, Oyo State and Hope Farm $^{\circledR}$, Ibadan Oyo State for the provision of the Day old chicks and antibiotic-free feed used for this study.

\section{REFERENCES}

Abouzeed YM, Hariharan H, Poppe C, Kibenge FSB (2000). Characterization of Salmonella isolates from beef, cattle, broiler chickens and human sources in Prince Edward Island. Comp. Immunol. Microbiol. Infect. Dis. 23:253-266.

Ahmed, AM, Younis EEA, Ishida Y, Shimamoto T (2009). Genetic basis of multidrug resistance in Salmonella enterica serovars Enteritidis and Typhimurium isolated from diarrheic calves in Egypt. Acta Tropica. 111:144-149.

Barrow GH, Feltham RKA (1993). Cowan and Steel's manual for identification of medical bacteria, 3rd Edn. Cambridge, UK, Cambridge University Press, p. 331.

Bäumler AJ, Tsolis RM, Ficht TA, Adams LG (1998). Evolution of host adaptation in Salmonella enterica. Infect. Immun. 66:4579-4587.

Berchieri Jr., A. (2000). Salmoneloses aviárias. In: Berchieri Jr, A., Macari, M. Doenças das aves. Facta, Campinas. pp. 185-196.

Bopp CA, Brenner FW, Fields PI, Wells JG, Stockbine NA(2003). Escherichia, Shigella, and Salmonella. In: Murray, P.R., Baron, E.J., Jorgensen, J.H., Pfaller, M.A., Yolken, R.H. (Eds.), Manual of Clinical Microbiology, ASM Press, Washington, D.C, 1(8):654-671.

Cambre RC, Green DE, Smith EE, Montali RJ, Bush M (1980). Salmonellosis and Arizonosis in the reptile collection at the national Zoological Park. J. Am. Vet. Med. Assoc. 177:800-803.

CDC (2012). Centers for Disease Control and Prevention 1600 Clifton Rd. Atlanta, GA 30333, USA 800-CDC-INFO (800-232-4636) TTY: 888:232-6348.

Clinical and Laboratory Standards Institute (2009). M07-A8. Methods for dilution antimicrobial susceptibility tests for bacteria that grow aerobically; approved standard. 8th ed. Wayne, PA.

Cooke FJ, Pinna ED, Maguire C, Guha S, Pickard DJ, Farrington M, Threlfall EJ (2009). First Report of Human Infection with Salmonella enterica Serovar Apapa Resulting from Exposure to a Pet Lizard. J. Clin. Microbiol. 47(8):2672-2674.

Ewing WH (1986). The genus Salmonella. In: Edward and Ewings' Identification of Enterobacteriaceae, 4th Edn. New York, NY, USA, Elsevier Science, pp. 181-340.

Frye FL (1981). Biomedical and surgical aspects of captive reptile husbandry. Edwardsville: Veterinary Medicine Publishing Company. 
Geue L, Löschner U (2002). Salmonella enterica in reptiles of German and Austrian origin. Vet. Microbiol. 84:79-91.

Greenberg Z, Sechter I (1992). Salmonella serotypes isolated from snakes and other reptiles - Israel, 1953-1989. Isr. J. Vet. Med. 47:49-60.

Jackson CG Jr, Jackson MM (1971). The frequency of Salmonella and arizona microorganisms in zoo turtles. J. Wildl. Dis. 7:130-132.

Kaufmann AF, Feeley JC, Wittwe DE (1967). Salmonella excretion by turtles. Public Health Rep. 82:840-842.

Kourany M, Myers CW, Schneider CR (1970). Panamanian amphibians and reptiles as carriers of Salmonella. Am. J. Trop. Med. Hyg. 19:632-638.

Kourany M, Porter JA Jr (1969). A survey for Enteropathogenic bacteria in Panamanian primates. Lab. Anim. Care 19:336-341.

Kourany M, Telford SR (1981). Lizards in the Ecology of Salmonellosis in Panama. Appl. Environ. Microbiol. 41:1248-1253.

Marcus LC (1981). Veterinary Biology and Medicine of Captive Amphibians and Reptiles. Philadelphia: Lea \& Febiger.

Miles AA, Misra SS, Irwin JO (1938). The estimation of the bactericidal power of the blood. J. Hyg. Comb. 38:732-748.

Monzon - Moreno C, Ojeda Vargas MM, Echeita A, Usera MA (1995). Occurrence of Salmonella in cold-blooded animals in Gran Canaria, Canary Islands, Spain. Antonie Van Leeuwenhoek 68:191-194.

Oboegbulem SI, Iseghohimhen AU (1985). Wall Geckos (Geckonidae) as reservoirs of Salmonellae in Nigeria: problems for epidemiology and public health. Int. J. Zoonoses 12(3):228-232.

Ogunleye AO, Ajuwape ATP, Adetosoye Al (2010). Infectious drug resistance plasmid study in Salmonella enterica isolates of domestic animals and lizards from some South-Western States of Nigeria. Afr. J. Biotechnol. 9(25):3726-3731.
Ogunleye AO, Carlson SA (2011). Survey of $3^{\text {rd }}$ generation cephalosporin genes in multi-resistant Salmonella serotypes from septic poultry and an asymptomatic healthy pig from Nigeria. Afr. J. Microbiol. Res. 5(15):2139-2144.

Otis VS, Behler JL (1973). The occurrence of Salmonellae and Edwardsiella in the turtles of the New York zoological park. J. Wildl. Dis. 9:4-6.

Raphael SS (1976). Lynch's medical laboratory technology, $3^{\text {rd }}$ Edn. Philadelphia, PA, USA, WB Saunders, pp. 876-933.

Ribeiro SAM, de Paiva JB, Zotesso F, Lemos MVF, Berchieri Jr A (2009). Molecular differentiation between Salmonella enterica subsp enterica serovar Pullorum and Salmonella enterica subsp enterica serovar Gallinarum. Braz. J. Microbiol. 40:184-188.

Will R (1975). Die Entstehungsursachen (Atiologie) der Lebererkrankungen bei Reptilien. Zentralbl Veterinaermed B. 22:626634.

Zwart P (1960). Salmonella and Arizona infections in reptiles in the Netherlands. Anton Van Leeuwenhoek J. Microb. Serol. 26:250-254.

Zwart P, Poelma FGSWJ (1970). The distribution of various types of Salmonellae and Arizonas in reptiles. Zentralbl. Bakteriol. pp. 201212. 